Proc. $3^{d}$ All Africa Conf. Anim. Agric. \& $11^{\text {th }}$ Conf. Egyptian Soc. Anim. Prod., Alexandria. Egypt, 6.9 November $200 k$ : $18^{7} .191$

\title{
FEED INTAKE AND BODY WEIGHT GAINS OF TSWANA SHEEP FED ON BUFFEL GRASS HAY AND SUPPLEMENTS UNDER DRYLOTTING
}

\section{A. A. Aganga and S. Managoba}

Department of Animal Science and Production, Botswana College of Agriculture, Private Bag 0027, Gaborone, Botswana

\section{SUMMARY}

Twenty eight yearling sheep ( 16 non -pregnant, non lactating and 12 castrated males) were used for a feeding trial conducted at Botswana college of Agriculture, content Farm, Gaborone, for a period of 125 days. The study was to investigate the performance of Tswana sheep under drylot feeding lucerne, sorghum bran, caged layer waste (CLW) and broiler litter as supplements. All animals were fed buffel grass hay plus supplements and lucerne was fed to the control group as supplement. Water was provided daily and mineral block offered ad- lib to all sheep. Both water and feed left overs were measured and recorded. The animals were weighed every fortnight before feeding. Feed analysis was done in the laboratory to determine nutritive values.

Average daily weight gain (g) by Tswana sheep was $102.34,112.78,82.71$ and 73.31 for Luceme, sorghum bran. caged layer waste and broiler litter respectively. there was significant difference in daily weight gains at $(p<0.05)$. Sheep fed on sorghum bran had a highter daily weight gain $(112.78 \pm 1.1)$ compared with sheep on lucerne at $(102.34 \pm 1.2)$. Treatment effects on daily lotal DM intake by sheep were significant at $(\mathrm{p}<0.05$ ). The control sheep had $860 \pm 18.90$ daity feed intake wlile those fed on sorghum bran had the highest $955 \pm 21.04$ and those on CLW had the least 893.33 \pm 11 .53. Supplement intake was significantly different at $(\rho<0.05)$, lucerne intake was $426.48 \pm 2.53$ while broiler litter intake was the least $339.80 \pm 2.53$.

There was no significant difference $(p>0,05)$ in the daily walcr intake by slicep. Those fed lucerne had the lighest water intake of $1430 \pm 26.14 \mathrm{ml}$ and those fed on broiler litter had the least

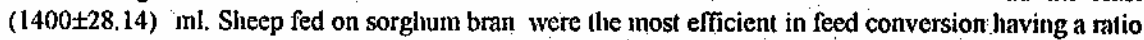
of $(8.47 \pm 0.16)$ and lucerne $(8.58 \pm 0.23)$ and the least being broiler litter $(12.34 \pm 0.16)$. This study indicated that supplements such as CLW, sorghum bran and broiler litter can be used to replace lucerne as suppleinent for the Tswana sheep fed on buffel grass hioy as bisal diet.

Keywords: Tswana sheep, drylotting, supplements, lucerne, cage layer waste, broiler litter

\section{INTRODUCTION}

The people of Botswana, recognize the important role that small ruminants play in the economy of the country especially among the small farmers to whom these animals provide meat, milk for home consumption. and cash income from sale of breeding animals (Aganga et.al 1998). The economic importance of the slieep depends on the value of their produce or services. Sheep are a way of converting poor quality forage into desirable products, they are a form of invesiment. The advantages of keeping sheep are low cost, little feed needed, manageable quantities of products and there is low risk of total loss (Bundy et. al., 1982). Drylot feeding consists of confining the sheep in a lot devoid of green feed and using a combination of the various cured forage feeds, grains and prolein supplements to bring the sheep up to the desired weight and finish (Charray 1992). In dry lot feeding the sheep are kept for $90-120$ days or even more for the finishing /fattening. This system allows the flock to be split into groups based on age, sex which is difficult when grazing. The most important biological principle in considering efficient production is that the animal should gain weight so that it reaches a weight suitable for slaughter within a reasonable period of time; thus nutrient intake must exceed requirements for maintenance of body weight.

The rations used for feeding may consist of roughage ( $50 \%$ of the total diet) and concentrate $(50 \%$ of the total diet) (Aganga et al., 1998). High quality legume hay is recognised as the most nutritional roughage. It is high in protein, minerals and vitanins. Supplementation helps in "providing those nutrierits that are not available in the feed. Legume forages have shown to be good supplements to poor quality fibrous diets. Lucene produces herbage high in dry matter and crude protein. When legume hay is fed; sheep usually make very satisfactory gains on legume hay and some cereal as the entire ration. Feeding trials have shown somewhat higher gains when protein supplements are fed to sheep receiving ligh protein roughage. Aganga et al.; (1998) stated that poultry droppings is a renewable source for 
nitrogen in Botswana. They noted that broiler droppings contain $20-30 \% \mathrm{CP}$ on dry malter basis. This amount of nitrogen can be tutilised efficiently when recycled through ruminant animals as feed Nitrogen is required in sheep feed for maintenance and weight equilibrium. Most tropical grasses and utilisation by efficiency of fermentable activity in the rilisation of the energy of such feeds is highly dependent upon the when fed different supplements under drye rumen. This study focused on performance of Tswana sheep

\section{MATERIALS AND METHODS}

This trial was conducted at Botswana College of Agriculture, sebele Gaborone, for 125 days: Four separate feed treatments were allocated to 4 groups of yearling sheep, 7 animals per treatment.

\begin{tabular}{lll}
\hline Treatment & Supplement(50\%) & Roughage(50\%) \\
\hline Control & Lucerne & Buffel grass hay \\
1 & Sorghum bran & Buffel grass hay \\
2 & Caged layer waste(CLW) & Buffel grass hay \\
\hline & Broiler litter (BL) & Buffel grass hay \\
\hline
\end{tabular}

Other feeds provided to the sheep were mineral block -free choice and molasses of $100 \mathrm{~g} / \mathrm{head}$ day.Poultry litter being broiler waste, which included poultry excreta, feathers, spilled feed and the bedding. Cage litter waste (CLW) included excreta, feathers, broken eggs, and spilled feeds. Both the CLW and broiler litter were collected from the college poultry house. Processing was done by sun drying which included spreading an approximately $1-2 \mathrm{~cm}$ thick layer of the B.L and the CLW on separate sheets and raked thoroughly twice a day; midday and in the afternoon. Drying lasted 2-3 days depending on weather conditions. The dried crispy litter was put in $50 \mathrm{~kg}$ bags. The dryness of the litter was measured by pressing between the fingers. When it was dried it shattered between the fingers.

Twenty eight yearling sheep, consisting of 16 non-pregnant females, non-lactating and 12 castrated males. The sheep were de-wormed and vaccinated against botulism, weighed and balanced for weight and sex into 4 treatment groups. Allocation was done using a completely randomised block design such that each group had 4 females, and 3 males making a total of 7 animals per group. The sheep were housed in separate pens, under a common roof measuring $2 \mathrm{~m}$ by $1 \mathrm{~m}$ with concrete floors. Cleaning of the floors was done every morning just before feeding. Feeding of the animals was done every morning at $0800 \mathrm{a} . \mathrm{m}$. and the feed left-overs removed every moming before the day's feed was introduced to the animals. The daily feed intake and refusals were weighed and recorded. The animals were watered daily experimental as measured using a measuring cylinder and recorded. All the experimental animals were weighed using an Avery walk-in scale before commencing the trial and weights were taken every fortnight until the end of the study.

Representative samples of the feeds were collected and put in small sampling bags. The samples again and the obtained put in the oven at $40^{\circ} \mathrm{c}$ for 72 hours. The oven dried samples were weighed again and the obtained weight and the initial weight were used to calculate the respective feed dry labelled and stored in air -tight samples were ground using a laboratory hammer mill and were AOAC (1995), the feed samples were wers. Ash content of the feeds was determined according to and the remoln placed in the muffle furnace at $600^{\circ} \mathrm{C}$ for 2 hours (1995) whereby the \%N was multiplied by 6.25 to was determined using the Kjeldahl method AOAC and the flame Neutral detergent fibre (NDF) used to determine the mineral contents of the feeds (AOAC, 199.5). Vitro digestibility were deterined acid detergent lignin (ADL) and indetermined using the SANYO Galenkame ANKOM (1997a\&b) procedures. Gross Energy (GE) was analysed statistically un calorimeter (AOAC,1995). The collected data were Torrie, 1980)

\section{RESULTS AND DISCUSSION}

From Table 1, chemical composition and DM content of the feed given to the sheep. sorghum bran has the highest DM of about 95.1 , followed by lucerne $94.1 \%$ given as hay, broiler litter $89.7 \%$, CLW $89.2 \%$ and $93.1 \%$ for buffel grass hay. Broiler litter had the highest crude protein (CP.) $21.9 \%$ and sorghum bran the least at $11.7 \%$. The ADF of broiler and lucerne were within the same range respectively $33.6 \%$ and $38.0 \%$ but buffel grass hay being the highest at $41.3 \%$ and the least being 
sorghum at $13.7 \%$. The NDF of Buffel grass hay was the highest at $71.0 \%$ and broiler litter at $67,1 \%$ with luceme and CLW in the same range and sorghum bran $28.9 \%$. CLW had the highest total minerals (ash) $20.1 \%$ with sorghum bran being the poor source of minerals $3.2 \%$. Lucerne at $9.0 \%$ and CLW at $19.3 \%$. Sorghum bran was the one with highest digestibility $88.3 \%$ and broiler litter $77.0 \%$. Lucerne was less digestible than CLW at $66 \%$ while CLW $74.4 \%$ among the supplements.

Table 1. Chemical composition of the experimental feeds,(\%DM) and GE of the feeds fed to the

\begin{tabular}{lccccccc}
\multicolumn{2}{c}{ sheep } & Lucerne & Sorghum bran & CLW & Broiler litter & Grass hay & Molasses \\
\hline DM \% & 94.1 & 95.1 & 89.2 & 89.7 & 93.1 & 94.1 \\
CP \% & 16.4 & 11.7 & 21.1 & 21.9 & 6.1 & 4.3 \\
ADF \% & 33.6 & 13.7 & 24.1 & 38.0 & 41.3 & - \\
NDF \% & 46.6 & 28.9 & 45.8 & 67.1 & 71.0 & - \\
ADL \% & 6.5 & 3.1 & 3.3 & 4.8 & 5.5 & - \\
IVTD \% & 66.0 & 88.3 & 74.4 & 277.0 & 47.6 & - \\
Ash \% & 9.0 & 3.2 & 20.1 & 19.3 & 9.7 & - \\
GE(Kcal/g) & 4.8 & 5.2 & 3.3 & 3.4 & 4.1 & 2.9 \\
\hline
\end{tabular}

Table 2 indicates mineral composition of the feeds; macro and micro minerals. CLW had the highest amount of calcium $33.7 \mathrm{~g} / \mathrm{kg}$, and sorghum bran contained the least calcium content $(2.5 \mathrm{~g} / \mathrm{kg})$. Sorghum bran and broiler litter had similar phosphorus content. Magnesium content in the feeds was higher in Lucerne $3.3 \mathrm{~g} / \mathrm{kg}$ and least in CLW $0.7 \mathrm{~g} / \mathrm{kg}$. Sodium content was generally low in all the feeds. Lucerne had more $\mathrm{K}$ than other feeds $2.4 \mathrm{~g} / \mathrm{kg}$ and sorghum bran had the least $1.2 \mathrm{~g} / \mathrm{kg}$ among the supplements but buffel grass hay had the highest at $10.1 \mathrm{~g} / \mathrm{kg}$. The micro minerals analysed were $\mathrm{Cu}, \mathrm{Fe}, \mathrm{Mn}, \mathrm{Zn}$. CLW and the highest $\mathrm{Cu}$ content $86 \mathrm{mg} / \mathrm{kg}$ was found in CLW and lucerne had the least at $10.3 \mathrm{mg} / \mathrm{kg}$. The highest content of Fe was $412 \mathrm{mg} / \mathrm{kg}$ in BL.

Table 2. Mineral composition of the feeds (DM Basis)

\begin{tabular}{|c|c|c|c|c|c|c|c|c|c|c|}
\hline \multirow[b]{2}{*}{ Feed } & \multicolumn{5}{|c|}{ Macro minerals in $\mathrm{g} / \mathrm{kg}$} & 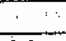 & \multicolumn{4}{|c|}{ Micro minerals in $\mathrm{mg} / \mathrm{kg}$} \\
\hline & $\mathrm{Ca}$ & $\mathbf{P}$ & Ca:P & $\mathbf{K}$ & $\mathrm{Na}$ & $\mathrm{Mg}$ & $\mathrm{Cu}$ & $\mathrm{Fe}$ & $\mathrm{Mn}$ & $\mathrm{Zn}$ \\
\hline Luceme & 8.8 & 1.9 & $4.53: 1$ & 2.4 & 0.4 & 3.3 & 10,3 & 352.0 & 48.3 & 41.3 \\
\hline Sorghum bran & 2.5 & 6.2 & $0.41: 1$ & 1.2 & 0.06 & 2.8 & 12.2 & 125.0 & 35.0 & $31: 0$ \\
\hline CLW & 33.7 & 20.9 & $1.61: 1$ & 0.7 & 2.4 & 1.7 & 86.0 & 400.0 & 341.0 & 190.0 \\
\hline Broiler litter & 8.4 & 7.0 & $1.19: 1$ & 1.4 & 0.2 & 3.0 & 59.7 & 412.0 & 400.0 & 197.0 \\
\hline $\begin{array}{l}\text { Buffel grass } \\
\text { hay }\end{array}$ & 13.1 & 0.8 & $16.17: 1$ & 10.1 & 0.3 & 1.3 & 16.5 & 200.0 & 200.3 & 1.5 \\
\hline
\end{tabular}

From Table 3; CLW fed sheep had the highest $\mathrm{CP}(\mathrm{g})$ intake per day and sorghum bran had the lowest intake while lucerne and broiler litter had $\mathrm{CP}(\mathrm{g})$ within the same range. Calcium intake was the highest in CLW fed sheep $194.54 \mathrm{~g}$ and the lowest being sorghum bran supplemented sheep $79.2 \mathrm{~g}$, Phosphorus, intake was lowest in sheep fed lucerne $12.65 \mathrm{~g}$ with the highest amount of $\mathrm{Mg} 21.52 \mathrm{~g}$. Water intake per day was relatively similar with the lowest water intake in sheep fed broiler litter $1400 \mathrm{ml}$ (table 4$)$. Body weight gain was significantly different among the treatments at $(\mathrm{p}<0.05)$ with the sheep fed sorghum bran at $12.86 \mathrm{~kg}$ and broiler litter fed sheep had $8,36 \mathrm{~kg}$. There was no significant difference in daily DM grass intake $(g)$ at $(p>0.05)$. Intake from the supplement was significantly different at $(p<0.05)$. Lucerne fed sheep had the highest intake at $426.48 \pm 3.58 \mathrm{~g}$ and broiler litter fed sheep had the lowest $339.80 \pm 2.53 \mathrm{~g}$.

Table 3. Daily nutrient intake of sheep

\begin{tabular}{|c|c|c|c|c|c|c|}
\hline Supplements & $\begin{array}{l}\text { Control } \\
\text { Lucerne }\end{array}$ & $\begin{array}{l}\mathrm{Tl} \\
\text { Sorghum }\end{array}$ & bran & $\begin{array}{l}\text { T2 } \\
\text { CLW }\end{array}$ & $\begin{array}{l}\mathrm{T} 3 \\
\mathrm{BL} \\
\end{array}$ & . \\
\hline $\mathrm{CP}(\mathrm{g}) / \mathrm{day}$ & 110.17 & 78.84 & & 113.84 & 109.92 & \\
\hline Gross Energy $(\mathrm{KJ} / \mathrm{g})$. & 12037.37 & 12039.05 & & 12031.09 & 12031.51 & \\
\hline $\mathrm{Ca}(\mathrm{g})$ & 107.45 & 79.23 & & 194.54 & 97.93 & $\therefore$ \\
\hline$P(g)$. & 12.65 & 27.081 & & 81.88 & 28.16 & . \\
\hline $\operatorname{Mg}(g)$ & 21.52 & 19.30 & & 10.15 & 10.19 & \\
\hline
\end{tabular}

Livestock productivity in Botswana is mainly limited by inadequate forage quality and/ or quantity during the long dry season which lasts for about 8 months in a year. Therefore, there is a need to supplement minerals, protein and vitamins obtained from grazing during this period. Protein is the 
nutrient found in highest concentration in organs. nuscles and tissues and as such it is important in feeding animals. As shown in Table I. which shows the chemical composition. DM. broiler litter had the lighest CP content $21.86 \%$. This is in agreement with Cross and Jenny (1998). They reported that litter can be low in CP because of excess volatilization of nitrogen in the poultry house. High temperature and excess moisture in the poultry house leads to nitrogen volatilisation. If the $C P$ values are less than $18 \%$, the litter should be used only as a fertilizer and not as a feed source. Lucerne CP was similar to that reported by Aganga and Monyatsiwa, (1999). Lucerne as a legume is expected to provide enough protein to the animal and can be used as a supplement in ruminant feeding on poor quality grass as basal diel.

Table 4. Intake and response of Tswana sheep during the experimental period

\begin{tabular}{|c|c|c|c|c|}
\hline Supplements & $\begin{array}{l}\text { Control } \\
\text { Lucerne }\end{array}$ & $\begin{array}{l}\text { Treatunent I } \\
\text { Sorgluum bran }\end{array}$ & $\begin{array}{l}\text { Treatment } 2 \\
\text { CLW }\end{array}$ & $\begin{array}{l}\text { Treatment } 3 \\
\text { Broiler lillcr }\end{array}$ \\
\hline Initial weight(kg) & $19.29 \pm 1.0$ & $18.29 \pm 2.13$ & $20.43 \pm 3.9$ & $19.1+ \pm 1.8$ \\
\hline Final body weight(kg) & $30.71 \pm 2.2$ & 2.3 & $29 \pm 3.0$ & 2.2 \\
\hline Body weight gained(kg) & $11.67 \pm 1.7^{\mathrm{a}}$ & $12.86 \pm 1.68^{\mathrm{a}}$ & $9,43 \pm 1,5^{b}$ & 8.36 \\
\hline Average daily body weight gain(g) & $102.34 \pm 1.2^{\mathrm{a}}$ & $112.78 \pm 1.1^{\mathrm{a}}$ & $82.71 \pm 1.3^{\mathrm{b}}$ & $73.31 \pm 1.6^{\mathrm{b}}$ \\
\hline Average daily DM grass intake(g) & $527.73 \pm 7.86^{\mathrm{a}}$ & $525.680 \pm 8.71^{1 \mathrm{n}}$ & $524.88 \pm 7.75^{n}$ & $522.29 \pm 6.97^{3}$ \\
\hline verage daily supplement(g) & $426.48 \pm 3.58^{\mathrm{a}}$ & $370.64 \pm 2.47^{b}$ & $370.59 \pm 2.47^{6}$ & $339.80 \pm 2.53^{\mathrm{c}}$ \\
\hline DM feed intake(g) & $860.54 \pm 18.90^{b}$ & $955.20 \pm 21.04^{n}$ & $893.43 \pm 1.53^{b}$ & $904.43 \pm 18.22^{\mathrm{l}}$ \\
\hline Average daily water intake(ml) & $1430 \pm 26.14^{\mathrm{a}}$ & $1430 \pm 25.14^{\mathrm{a}}$ & $1420 \pm 30.01^{a}$ & $1400 \pm 28.14^{\mathrm{a}}$ \\
\hline Feed conversion DM/gain & $8.58 \pm 0.23^{b}$ & $8.47 \pm 0.16^{b}$ & $10.81 \pm 0.03^{\mathrm{a}}$ & $12.34 \pm 0.16^{\mathrm{a}}$ \\
\hline
\end{tabular}

Broiler litter had the higlest amount of ash content of $20.14 \%$. since it contains saw dust or wood shavings. but ash content above $28 \%$ in the litter should not be fed to ruminanis since such trigh ash levels indicate that large amounts of soil contaminaled the litter. Litter will a high ash content will result in poor consumption and subsequent poor animal performance (Cross and Jenny.1998). As shown in Table 4: sorghum bran fed sheep had the highest body weiglit gained $12.86 \pm 1.68 \mathrm{~kg}$ with the highest feed conversion $8.47 \mathrm{~g} / \mathrm{g}$ which was comparable with sheep fed on lucerne. The implication is that feeding sheep lucerne as supplement can be as good as feeding sorghum bran, with feed conversion ratio not significantly different at $(p>0.05)$. Broiler litter fed sheep had the least body weight gain $(\mathrm{kg})$ $8.36 \pm 1.4$ and the least efficient feed conversion ratio $12.34 \mathrm{~g} / \mathrm{g}$, this in line with the findings of Cross and Jemy (1998) that found that broiler litter substituted in high grains diets resulted in a reduction in daily gains and a lower feed conversion ratio. Performance of sheep supplemented with broiler litter was not significantly different from those supplemented on CLW.

Sorghum bran fed sheep had the highest average daily gain (g) (ADG) $112.78 \pm 1.6$ as compared to that of broiler litter $73.31+1.6$. The DM intake in relation to gain of sheep supplemenied on CLW was higher compared to those on broiler litter, this is in agreement with the findings of Ayangbile and Tallam.1992; who reported better feed conversion for sheep supplemented with deep stacked CLW in kenva. Daily total DM intake was highest with sorghum bidn, this might be due to its high digestibilty. Average daily DM supplement intake was highest in control sheep fed with Lucerne. The main reason for the differences in intake between feeds appear to be the same as that which relates to digestibility that the more rapidly a feed is digested and leaves the rumen the quicker is space made available in the rumen and the more of that feed the animal can eat. Sheep fed on broiler litter had the lowest intake of supplement due to its unpalatibility as reported by Cross and Jenny (1998). Broiler litter is not as palatable as other common feed sources, and sheep require a period of time to get adjusted to it. To make it more palatable. it is usually mixed with more palatable feeds such as corn. milo. commercial grain mixes and soybean lulls. Raw broiler litter necds to be processed to ensure its safety ' from potentially harmful palhogens. Processing can be achieved by moderate heal, either during the ensiling process, sun drying, or deep stacking the broiler litter (Ayangbile and Tallam, 1992). The palatability was enhanced by sprinkling the ration with $100 \mathrm{~g}$ molasses powder in this study. The water intake in millineter was comparable with all the rations, indicating that intake of all the supplement did not affect water consumption. Sheep on Lucerne and Sorglum bran had almost the same amount $1430 \mathrm{ml} /$ head /day .

Minerals are important in the development of the body of an animal. Therefore it is important to know the mineral composition of a particular feed given to the animals. Mineral deficiencies and toxicities do occur in the body. Both. Ca and $\mathrm{P}$ are found in high concentration in the animal's body and are imporlant constituents of the skeleton and teeth. Inbalance in Ca and $P$ results in rickets in young growing animals and osleomalacia in mature animals. A ratio of $2: 1$ must be inaintained. The results 
from table 3 and table 4 shows that CLW has the highest amount of $\mathrm{Ca}$, it might be attributed to high amounts of $\mathrm{Ca}$ needed for the formation of egg shell: Lucerne and broiler litter had no significant difference in their amounts of $\mathrm{Ca}$.Cereals are low in calcium and if extra $\mathrm{Ca}$ is not given to bring the ratio of Ca:P (2:1) male lamb will suffer from Urolithiasis ( blockage of urine passage) (Speedy 1990). Too little micro minerals can be as dangerous as too much of them. Copper toxicity has been a problem widely reported when broiler litter is fed to sheep (Cross and Jenny ,1998) therefore, when feeding broiler litter it should not be fed continuously for more than 5 months. Lucerne and sorglum bran had the least amount of $\mathrm{Cu} 10.3 \mathrm{ng} / \mathrm{kg}$ and $12.23 \mathrm{mg} / \mathrm{kg}$ respectively and which can then be recommended for feeding sheep in a drylot since it will provide adequate $C u$ to the animals and not excess thus; no possible problem of $\mathrm{Cu}$ poisoning.

\section{CONCLUSION}

The study showed that poultry waste, sorghum bran and lucerne can provide a protein source as they are rich in crude protein and therefore can be used as supplement to low quality forages. Body weight gains of Tswana sheep fed Lucerne as supplemient were similar to that fed sorghum bran, while CLW and broiler litter were also similar. Daily intake of lucerne was the highest with sorghum bran and CLW being the same while broiler litter had the lowest intake. Feed conversion ratio was similar between sheep fed Lucerne and those fed sorghum bran. This shows that Tswana sheep can utilise sorghum bran as efficiently as they utilise Lucerne.

\section{REFERENCE}

Aganga A. A. and Monyatsiwa C. B., 1999. Use of browse (Terminalia serecia, Combretum apiculatum or Euclea schimperi) as a supplement for growing Tswana goats. Tropical Animal Health and Production 31:295-305

Aganga A.A. Setimela S. and Mbaiwa W., 1998. Poultry Droppings as Protein Supplement for Tswana Goats. Thai Journal of Agricultural Science: $31: 467-473$

Ankom, 1997a. Ankom ${ }^{200 / 220}$ Fiber Analyzer Manual, Ankom Techology, 140 Turk Hill Park, Fairport, NY 14450

Ankom, 1997b. Ankom ${ }^{200220}$ Rumen Fermenter, Ankom Techology, 140 Turk Hill Park, Fairport, NY 1440

Association of Official analytical Chemists AOAC, 1995, Official Methods of Analysis ,Arlington. Virginia, USA $\left(16^{\text {th }}\right.$ ed).

Ayangbile O. A. and Tallam S. K., 1992. Performance of sheep fed processed poultry excreta as protein supplement. Tropical Agriculture (Trinidad) 69: 49-50.

Bundy C. E., Diggins R.V. and Christensen V. W., 1982 Livestock and Poultry.production. Prentice Hall, New Jersey.

Charray J., 1992. Manual of Sheep Production in the Humid Tropics of Africa. Wallingford CAB international.

Cross F. T. and Jenny F. H., 1998, Broiler litter as as a source of non protein nitrogen. Extension Services, Missisippi State University, USA.

Steel R. G. 'D. and Torrie J.H., 1980. Principles and Procedures of Statistics. A Biometrical Approach, $2^{\text {nd }}$ edition, McGraw-hill publishing company incorporated, New York,USA. 